\title{
Implikasi Erupsi Gunung Agung Terhadap Usaha Pariwisata Di Daya Tarik Wisata Bahari Tulamben, Kecamatan Kubu, Kabupaten Karangasem
}

Ida Ayu Karina Putri a,1 I Made Adikampana a,2

1idaayukarinaputri@gmail.com2adikampana@unud.ac.id

a Program Studi Sarjana Destinasi Pariwisata, Fakultas Pariwisata, Universitas Udayana, Jl. Dr. R. Goris, Denpasar, Bali 80232 Indonesia

\section{Abstract}

Tulamben Marine Tourist Attraction it has a variety of tourism business such as, tourist accommodations, diving and snorkeling occupations, porter professions also food and beverage services. Mount Agung status alert, on October 22nd, 2017 some residents within radius of $12 \mathrm{~km}$ are evacuated to several areas in Bali. The evacuated people are living in 28 villages in Karangasem regency, one of them is Tulamben Village. Mount Agung eruption has a direct impact on tourism bussiness. This study aims to analyze the implication of Mount Agung Eruption on Tourism Business at Tulamben Marine Attraction, Kubu Sub-District, Karangasem Regency. The research method used is qualitative study with descriptive analysis technique to examine the implications of Mount Agung eruption on tourism business. Source data from primary knowledges and secondary documents. Data are collected through observation methods, interviews, literature study, and research instruments in the form of interview guidelines. The informants are determinated by using purposive sampling technique to obtain accurate data about the type of tourism business and the implications of eruption of Mount Agung to the tourism business service in Tulamben Marine Tourist Attraction.

Keywords: Marine Tourist Atrraction, Eruption, and Tourism Bussines

\section{PENDAHULUAN}

Kabupaten Karangasem memiliki daya tarik wisata alam seperti wisata bahari, agrowisata, wisata arung jeram dan pariwisata budaya seperti wisata sejarah dan wisata religi. Kabupaten Karangasem terus melakukan perencanaan dan pengembangan pada daya tarik wisata bahari. Salah satu daya tarik wisata wisata bahari yang mendapatkan perhatian khusus yaitu Daya Tarik Wisata Bahari Tulamben (Dinas Kebudayaan dan Pariwisata Kabupaten Karangasem, 2016).

Daya Tarik Wisata Bahari Tulamben merupakan salah satu daya tarik wisata bahari yang terletak di Desa Tulamben, Kecamatan Kubu, Kabupaten Karangasem. Potensi wisata bahari yang dimiliki oleh Daya tarik wisata bahari Tulamben yaitu kekayaan biota laut, keindahan panorama, dan keanekaragaman atraksi yang diberikan Tulamben menjadikan objek wisata bahari tersebut menjadi tempat terbaik untuk menyelam yang berada di Bali (Subhan, 2014).

Namun pada tanggal 22 Oktober 2017 terjadi erupsi Gunung Agung terletak di Kabupaten Karangasem yang menyebabkan pengaruh atau implikasi terhadap pengembangan Daya Tarik Wisata Bahari Tulamben. Masyarakat yang dievakuasi adalah yang tinggal pada radius $12 \mathrm{~km}$ di 28 desa di Kabupaten Karangasem, salah satunya Desa Tulamben. Desa Tulamben merupakan desa yang terdampak langsung terhadap bencana Gunung Agung setalah statusnya menjadi Awas atau pada level 4 atau zona merah di Desa Tulamben masuk dalam KRB (Kawasan Rencana Bencana). Zona merah KRB tidak diperbolehkan ada aktivitas apapun di Desa Tulamben. Sehingga semua warga dianjurkan untuk mengungsi ke berbagai wilayah yang aman di Bali. Dengan penetapan Desa Tulamben masuk KRB 2 maka aktivitas tidak ada sama sekali, termasuk kegiatan pariwisata Dengan penetapan Desa Tulamben masuk dalam KRB 2 maka aktivitas tidak ada beroperasi termasuk kegiatan pariwisata. (Suastika, 2017)

Penduduk di Daya Tarik Wisata Bahari Tulamben bergantung dengan sektor pariwisata, hal tersebut dapat dilihat dari usaha pariwisata di sektor pariwisata seperti menjadi pegawai akomodasi, pegawai restoran, pemandu diving, porter, dan pengelola atau pemilik usaha pariwisata yang terdapat di daya tarik wisata tersebut. Erupsi Gunung Agung memberikan pengaruh secara langsung dalam usaha jasa pariwisata yaitu perubahan operasional, penurunan okupansi dan hubungan pekerjaan

Penelitian ini menjadi sangat penting untuk mengetahui implikasi erupsi Gunung Agung terhadap usaha pariwisata di Daya Tarik Wisata Bahari Tulamben, Kecamatan Kubu, Kabupaten Tulamben 


\section{KEPUSTAKAAN}

Penelitian tentang kepariwisataan mengenai implikasi bencana alam terhadap sektor pariwisata di daya tarik wisata sudah dilakukan oleh beberapa peneliti. Kajian kepustakaan menggunakan jurnal penelitian yang telah dipublikasi, adapun jurnal penelitian tersebut diantaranya penelitian yaitu "Dampak Erupsi Gunung Sinabung Terhadap Pendapatan Dari Sektor Pariwisata Di Kabupaten Karo" oleh Febriaty (2015). Persamaan penelitian tersebut dengan penelitian ini adalah terletak di kajian permasalahan yaitu dampak dari bencana alam (erupsi gunung berapi dan Penelitian "Dampak Pariwisata Terhadap Mata Pencaharian Masyarakat Pesisir Karangasem: Pendekatan Pro Poor Tourism" oleh Suardana dan Dewi (2015). Perbedaan dengan penelitian tersebut yaitu terletak pada lokasi studi kasus yaitu di Kabupaten Karangasem.

Penelitian ini menggunakan beberapa konsep yaitu diantaranya pengertian implikasi (Echols dan Shadily, 1989), wisata bahari (Muljadi, 2014), usaha pariwisata (UU RI No. 10 Tentang Kepariwisataan Tahun 2009) dan manajemen krisis (Fearn dan Banks, 1996 dalam Sugiarti, 2012).

\section{METODE PENELITIAN}

Penelitian ini dilaksanakan di Daya Tarik Wisata Bahari Tulamben yang terletak di Desa Tulamben, Kecamatan Kubu, Kabupaten Karangasem, Provinsi Bali. Berdasarkan arah Badan Meteorologi, Klimatologi dan Geofisika (BMKG), Desa Tulamben merupakan salah satu kawasan rawan bencana tingkat II yang sangat berdampak langsung terhadap kehidupan masyarakat termasuk kegiatan usaha pariwisata.

Teknik pengumpulan data dalam penelitian ini yaitu observasi dengan tujuan untuk pengamatan lokasi studi permasalahan, wawancara dengan Kepala Perbekel Desa Tulamben, BMKG, Dinas Pariwisata dan Kebudayaan Kabupaten Karangasem, Dinas Pariwisata Provinsi Bali, pengusaha atau staff perusahaan akomodasi di Daya Tarik Wisata Bahari Tulamben, pengelola dan pemandu diving dan snorkeling di Daya Tarik Wisata Bahari Tulamben, tenaga porter, karyawan di usaha makan dan minum di Daya Tarik Wisata Bahari Tulamben dan studi kepustakaan.
Analisis data yang digunakan dalam penelitian ini adalah teknik deskriptif kualitatif. Data yang diperoleh lalu ditulis dan diuraikan berbentuk deskripsi yang jelas dan obyektif mengenai data tentang implikasi erupsi Gunung Agung terhadap usaha pariwisata di Daya Tarik Wisata Bahari Tulamben.

\section{HASIL DAN PEMBAHASAN}

\section{Implikasi Terhadap Usaha Akomodasi}

Daya Tarik Wisata Bahari Tulamben memiliki beragam bentuk usaha akomodasi mulai dari homestay, resort, vila, hingga hotel

Berdasarkan pengamatan dan wawancara yang telah dilakukan bahwa pasca erupsi Gunung Agung memiliki pengaruh yang cukup besar terhadap usaha akomodasi

Perubahan operasional pada usaha akomodasi pasca erupsi Gunung Agung yaitu menerapkan sistem jam kerja tidak tetap. Dalam kondisi normal usaha akomodasi pariwisata di Daya Tarik Wisata Bahari Tulamben jam operasional staff dan pegawai adalah 8 jam dengan menerapkan sistem shift dengan mengelola pembagian jobdesk karyawan menjadi tiga shift yaitu pagi, siang dan malam.

Perubahan operasional memiliki keterkaitan dengan pendapatan (tingkat hunian) terhadap usaha akomodasi. Pengusaha perusahaan usaha jasa hingga memberikan potongan harga 30 persen untuk wisatawan. Penurunan okupansi tersebut menyebabkan pengusaha tidak dapat membayar kompensasi (gaji) kepada karyawan secara penuh (full).

Secara tidak sadar penurunan okupansi bersinggungan dengan etos kerja dan pudarnya semangat kerja karyawan di suatu usaha akomodasi di Daya Tarik Wisata Bahari Tulamben hingga menyebabkan karyawan memutuskan untuk mengundurkan diri dan kehilangan pekerjaan.

Upaya yang telah dilakukan pihak pengusaha usaha akomodasi di Daya Tarik Wisata Bahari seperti pemaparan di atas dalah dengan terus melakukan promosi dengan memberikan pemotongan harga untuk wisatawan yang akan menginap. Jika kunjungan wisatawan sudah normal tentu akan memulihkan krisis yang timbul seperti operasional usaha akomodasi akan kembali 
normal, okupansi perusahaan akan meningkat dengan perlahan, serta semangat kerja karyawan akan timbul kembali.

\section{Implikasi terhadap Usaha Diving dan Snorkeling}

Pantai Tulamben pasca erupsi Gunung Agung yang sangat tidak kondusif, wisatawan panik dan merasa tidak aman saat melakukan aktivitas penyelaman. Pasca erupsi Gunung Agung usaha diving dan snorkeling di Daya Tarik Wisata Bahari Tulamben merasakan dampak yang sangat memiliki keterkaitan besar terhadap perekonomian mereka seperti perubahan operasional dan penurunan pendapatan. Dahulu, operasional jam kerja penuh bahkan hingga malam hari karena ada permintaan dari wisatawan namun ketika aktivitas Gunung Agung semakin meningkat yang berberimplikasi terhadap jumlah kunjungan wisatawan yang menurun setiap harinya menyebabkan aktivitas diving dan snorkeling tidak optimal seperti kondisi normal. Jumlah kunjungan wisatawan yang menurun memiliki efek kepada pendapatan pemandu diving di Daya Tarik Wisata Bahari Tulamben. Pemandu diving hanya melakukan profesinya saat ada permintaan atau request dari wisatawan.

yaitu $\begin{gathered}\text { Permasalahan lainnya yang timbu } \\ \text { adanya perpindahan tangan }\end{gathered}$
kepemilikan usaha diving dan snorkeling milik masyarakat lokal menjadi milik investor asing. Masyarakat lokal menjual usaha diving dan snorkeling ke investor asing karena tak mampu untuk membayar perawatan fasilitas untuk penyelaman dan memenuhi kebutuhan karyawan seperti memberikan kompensasi. Hal tersebut merupakan dampak langsung erupsi Gunung Agung pada usaha jasa pariwisata yang sangat besar karena masyarakat lokal telah menjual usaha yang dimiliki kepada investor asing.

Upaya-upaya yang telah dilakukan pengusaha usaha jasa diving dan snorkeling pasca erupsi Gunung Agung di Daya Tarik Wisata Bahari Tulamben yaitu dengan hanya menggandalkan promosi dari media sosial dan mengajak kembali wisatawan repeater untuk berkunjung kembali.

\section{Implikasi terhadap Tenaga Porter}

Usaha diving dan tenaga porter memiliki hubungan profesi yang terkait yaitu porter sebagai suatu jasa dalam pengangkutan alatalat selam. Pasca erupsi Gunung Agung di Daya Tarik Wisata Bahari Tulamben yang memiliki atraksi utama penyelaman ke drop off Pantai Tulamben untuk melihat biota laut, berkaitan secara langsung terhadap porter. Seorang porter pada kondisi normal dapat mengangkut minimal 30 set alat selam perhari namun dengan adanya aktivitas Gunung Agung menyebabkan seorang porter hanya bisa mengangkut minimal 10 set alat selam perhari karena jumlah kunjungan wisatawan yang melakukan aktivitas penyelaman sedikit. Upaya yang dilakukan oleh pengelola jasa porter adalah hanya tetap menunggu panggilan dari usaha diving atau snorkeling terkait permintaan aktivitas.

\section{Implikasi terhadap Usaha Makanan dan Minnuman}

Usaha Jasa Makanan dan Minuman yang terdapat di Daya Tarik Wisata Bahari Tulamben tidak luput dari implikasi pasca erupsi Gunung Agung. Berdasarkan pengamatan yang dilakukan di sekitar Pantai Tulamben terdapat jejeran restoran yang sepi dan tidak ada pengunjung yang menyebabkan penurunan penerimaan (gaji) dan perubahan operasional restoran dan tempat makan. Upaya yang dilakukan adalah hanya tetap membuka restoran walaupun kunjungan wisatawan tidak seperti dahulu.

\section{Matriks Implikasi Erupsi Gunung Agung terhadap Usaha Pariwisata}

Matrik implikasi erupsi Gunung Agung terhadap usaha pariwisata dapat dilihat pada Tabel 1.

Tabel 1.

Matriks Implikasi Erupsi Terhadap Usaha Pariwisata di Daya Tarik Wisata Bahari Tulamben

\begin{tabular}{|c|c|c|c|}
\hline No & $\begin{array}{c}\text { Usaha } \\
\text { Pariwisata }\end{array}$ & Implikasi & $\begin{array}{c}\text { Upaya } \\
\text { Penyelesaian }\end{array}$ \\
\hline 1 & $\begin{array}{l}\text { Usaha } \\
\text { Akomodasi }\end{array}$ & $\begin{array}{l}\text { perubahan } \\
\text { operasional, } \\
\text { penurunan }\end{array}$ & $\begin{array}{l}\text { Promosi } \\
\text { menggunakan } \\
\text { sosial media }\end{array}$ \\
\hline
\end{tabular}




\begin{tabular}{|c|c|c|c|}
\hline & & $\begin{array}{l}\text { okupansi dan } \\
\text { kehilangan } \\
\text { Pekerjaan }\end{array}$ & $\begin{array}{l}\text { dengan } \\
\text { memberikan } \\
\text { potongan } \\
\text { harga }\end{array}$ \\
\hline 2 & $\begin{array}{l}\text { Usaha } \\
\text { Diving dan } \\
\text { Snorkeling }\end{array}$ & $\begin{array}{l}\text { Perubahan } \\
\text { operasional dan } \\
\text { penurunan } \\
\text { okupansi }\end{array}$ & $\begin{array}{l}\text { Promosi } \\
\text { menggunakan } \\
\text { sosial media }\end{array}$ \\
\hline 3 & $\begin{array}{l}\text { Usaha Jasa } \\
\text { Porter }\end{array}$ & $\begin{array}{l}\text { Kehilangan } \\
\text { pekerjaan }\end{array}$ & - \\
\hline 4 & $\begin{array}{l}\text { Usaha } \\
\text { Makan dan } \\
\text { Minum }\end{array}$ & $\begin{array}{l}\text { Perubahan } \\
\text { operasional dan } \\
\text { penurunan } \\
\text { pendapatam }\end{array}$ & Tetap buka \\
\hline
\end{tabular}

Sumber: Penelitian Lapangan III, 2018

\section{PENUTUP}

Daya Tarik Wisata Bahari Tulamben memiliki usaha pariwisata seperti perusahaan akomodasi, bisnis diving dan snorkeling, tenaga porter, dan usaha jasa makan dan minum. Namun, pasca erupsi Gunung Agung memiliki pengaruh secara langsung terhadap usaha pariwisata yang terdapat di Daya Tarik Wisata Bahari Tulamben seperti perubahan operasional, pengurangan pendapatan, dan kehilangan pekerjaan.

Rekomendasi yang diberikan kepada pemerintah dengan memberikan penyuluhan terkait kewaspadaan bencana alam, menyusun media branding replacement untuk pemulihan, menjadi fasilitator dalam promosi dan kerjasama nasional dan kerjasama internasional. Pengusaha pariwisata diharapkan keamanan wisatawan selama berkunjung dengan memberikan penawaran-penawaran menarik untuk wisatawan untuk meningkatkan jumlah kunjungan, memberikan pengertian untuk wisatawan terkait kenyamanan dan keamanan saat melalukan aktivitas pariwisata di Daya Tarik Wisata Tulamben. Masyarakat Lokal disarankan untuk mampu menggali potensi wisata yang terdapat di Daya Tarik Wisata Bahari Tulamben dengan menciptakan atraksi wisata yang baru dengan melibatkan penduduk setempat dan tidak mudah mengikuti arahan investor asing untuk menjual usaha atau sumber daya yang dimiliki.

\section{DAFTAR PUSTAKA}

Anomim. 2009. Undang-Undang Republik Indonesia No. 10 Tahun 2009. Tentang Kepariwisataan. Jakarta

Dinas Kebudayaan dan Pariwisata Kabupaten Karangasem. 2013. Data Kepariwisataan Kabupaten Karangasem. Amlapura

Echols, M. John dan Shadily Hasan, 1989. Kamus Indonesia - Inggris, Jakarta : Gramedia Pustaka Utama.

Febriaty, Hastina. 2015 "Dampak Erupsi Gunung Sinabung terhadap Pendapatan dari Sektor Pariwisata di Kabupaten Karo." Jurnal Ekonomikawan

Muljadi, A.J, Kepariwisataan dan Perjalanan. Jakarta: Raja Grafindo Persada

Suardana, Wayan I dan Susrami Dewi IGA. 2015. "Dampak Pariwisata terhadap Mata Pencaharian Masyarakat Pesisir Karangasem: Pendekatan Pro Poor Tourism." PIRAMIDA.

Suastika, Nyoman. 2017. Matinya Tulamben akibat Krisis Gunung Agung [Online] dalam https://balebengong.id/berita-utama/akibatkrisis-gunung-agung.html?lang=id diakses pada Rabu, 28 Februari 2018 pukul 19.00 WITA

Subhan, B. 2014 Kehidupan Laut Tropis Tulamben. Bogor: IPB Press

Sugiarti,Rini (2012). Managemen Krisis Candi Borobudur (Studi Desktiptif Kualitatif pada PT. Taman Wisata Candi Borobudur, Prambanan, dam Ratu Boko dalan Pelestarian World Heritage Pasca Erupsi Merapi. Yogyakarta: UIN Sunan Kalijaga 